\title{
PENGARUH KONSENTRASI MIKROBA SACCHAROMYSES CEREVISIAE DALAM PEMBUATAN BIOETANOL MENGGUNAKAN BAHAN CACAHAN TONGKOL JAGUNG MANIS
}

\section{The Effect of Microbial Concentration of Saccharomyses Cerevisiae in the Production of Bioetanol using Ingredients of Sweet Corn Cob}

\author{
Maulana Akbar Al Aziz ${ }^{1, *}$, Ropiudin², Abdul Mukhlis Ritonga ${ }^{2}$ \\ ${ }^{1}$ Mahasiswa Program Studi Teknik Pertanian - Jurusan Teknologi Pertanian \\ Universitas Jenderal Soedirman \\ ${ }^{2}$ Staf Pengajar Program Studi Teknik Pertanian - Jurusan Teknologi Pertanian \\ Universitas Jenderal Soedirman \\ *Korespondensi, Email: maulana11155@gmail.com
}

DOI: https://doi.org/10.20884/1.jaber.2021.2.1.4019

Naskah ini diterima pada 10 Maret 2021; revisi pada 2 April 2021;

disetujui untuk dipublikasikan pada 10 Mei 2021

\begin{abstract}
ABSTRAK
Kebutuhan energi bahan bakar yang berasal dari eksplorasi fosil terus meningkat seiring dengan meningkatnya pertumbuhan industri dan ekonomi. Hal tersebut dapat menjadi masalah ketika negara belum bisa mengurangi ketergantungan terhadap bahan bakar fosil atau bahan bakar minyak (BBM), sedangkan cadangan sumber energi tersebut makin terbatas. Kebijakan mengurangi konsumsi energi bukan merupakan langkah tepat. Bioetanol merupakan jenis energi yang berpotensi ditawarkan untuk mengurangi ketergantungan pada energi fosil. Bioetanol dapat diproduksi dari bahan baku tanaman yang mengandung pati atau karbohidrat. Penelitian ini dilaksanakan di Laboratorium Teknik Sistem Termal dan Energi Terbarukan dan Laboratorium Pangan dan Gizi, Universitas Jenderal Soedirman. Penelitian ini dilaksanakan pada bulan Januari 2020 sampai dengan September 2020. Penelitian ini menggunakan Rancangan Acak Lengkap (RAL) dengan dua faktor yaitu konsentrasi mikroba Saccharomyces Cereviceae 0\%, 5\%, 7,5\% dan 10\% dan lama fermentasi 2 hari, 4 hari, dan 6 hari. Masing-masing perlakuan diulang sebanyak 3 kali sehingga terdapat 36 unit percobaan. Variabel yang diamati yaitu kadar gula reduksi, kadar bioetanol, dan rendemen bioetanol. Penelitian ini bertujuan untuk mengetahui kadar bioetanol yang dihasilkan dari cacahan tongkol jagung manis dan mengetahui pengaruh konsentrasi mikroba Saccharomyses Cereviceae dan waktu fermentasi dalam memproduksi bioetanol dari tongkol jagung manis yang dicacah. Hasil penelitian menunjukan bahwa tongkol jagung manis memiliki kadar air 84\% basis basah dan kadar gula 2,21\%. Perlakuan konsentrasi mikroba 0\% dengan waktu fermentasi 6 hari menghasilkan kadar gula reduksi paling tinggi yaitu 1,142\% (m/v). Konsentrasi mikroba Saccharomyses Cereviceae tidak berpengaruh nyata terhadap produksi kadar gula reduksi, sedangkan waktu fermentasi berpengaruh nyata terhadap produksi kadar gula reduksi. Rata-rata kadar bioetanol tertinggi sebesar 0,557\% (v/v) hasil kombinasi perlakuan konsentrasi mikroba 7,5\% dengan waktu fermentasi 4 hari (S3T2).
\end{abstract}

Kata kunci: Bioetanol, Tongkol jagung manis, Saccharomyces Cereviceae

\section{ABSTRACT}

The need for fuel energy originating from fossil exploration continues to increase in line with the increasing industrial and economic growth. This can be a problem when the country has not been able to reduce dependence on fossil fuels or oil fuels $(B B M)$, while the reserves of these energy sources are increasingly limited. The policy of reduce energy consumption is not the right step. Bioethanol is a type of 
energy that has the potential to be offered to reduce dependence on fossil energy. Bioethanol can be produced from plant raw materials which contain starch or carbohydrates This research will be carried out at the Thermal System and Renewable Energy Engineering Laboratory and the Food and Nutrition Laboratory, Jenderal Soedirman University. This research was carried out from January 2020 until September 2020. This research used a completely randomized design (CRD) with two factors namely the concentration of Saccharomyces Cereviceae microbes 0\%, 5\%, 7.5\% and 10\% and fermentation time of 2 days, 4 days, and 6 days. Each treatment was repeated 3 times so that there were 36 experimental units. The observed variables were reducing sugar content, bioethanol content, and bioethanol yield. This research aims to determine the levels of bioethanol produced from chopped sweet corn cobs and to determine the effect of the microbial concentration of Saccharomyces Cereviceae microbes and fermentation time in producing bioethanol from chopped sweet corn cobs. The results showed that sweet corn cobs had a water content of $84 \%$ wet base and a sugar content of $2.21 \%$. Treatment of $0 \%$ microbial concentration with a fermentation time of 6 days resulted in the highest reducing sugar content, namely $1.142 \%(\mathrm{~m} / \mathrm{v})$. The concentration of Saccharomyses Cereviceae microbes did not significantly affect the production of reducing sugar levels, while the fermentation time had a significant effect on the production reducing sugar levels. The highest average bioethanol content of $0.557 \%(\mathrm{v} / \mathrm{v})$ resulted from a combination of $7.5 \%$ microbial concentration treatment with 4 days of fermentation time (S3T2).

Keywords: Bioethanol, Sweet corn cobs, Saccharomyces Cereviceae

\section{PENDAHULUAN}

Kebutuhan energi bahan bakar yang berasal dari eksplorasi fosil terus meningkat seiring dengan meningkatnya pertumbuhan industri dan ekonomi. Hal tersebut dapat menjadi masalah ketika negara belum bisa mengurangi ketergantungan terhadap bahan bakar fosil atau bahan bakar minyak (BBM), sedangkan cadangan sumber energi tersebut makin terbatas. Fluktuasi suplai dan harga minyak bumi yang terjadi seharusnya membuat kita sadar bahwa jumlah cadangan minyak semakin menipis. Kebijakan mengurangi konsumsi energi bukan merupakan langkah tepat. Karena jumlah penduduk yang banyak juga akan berumpan balik dengan penggunaan energi yang banyak.

Karena konsumsi energi dan pertumbuhan ekonomi merupakan dua sisi yang saling mempengaruhi, diperlukan kehati-hatian dalam menerapkan kebijakan energi agar pertumbuhan ekonomi tetap terjaga. Supaya perekonomian dunia lebih stabil, penggunaan sumber energi alternatif dengan bahan baku non-fosil seperti bahan bakar dari sumber nabati dapat menjadi solusi yang baik. Pembakaran bahan bakar fosil juga akan menghasilkan gas $\mathrm{CO}_{2}$ kelamaan akan menumpuk di atmosfer, sehingga menyebabkan suhu bumi meningkat (green house effect). Oleh karena itu, pemakaian suatu bahan bakar terbarukan yang lebih aman dan ramah lingkungan merupakan suatu hal alternatif dalam usaha inovasi penghematan energi secara realistis. Sehingga bahan yang disebut limbah dapat dimanfaatkan sehingga tidak terbuang secara sia-sia.

Bioetanol dapat diproduksi dari bahan baku tanaman yang mengandung pati atau karbohidrat. Sumber bahan baku energi alternatif tersebut umumnya berasal dari tanaman pangan, seperti singkong, ubi jalar, tebu, jagung, dan lain-lain. Namun, penggunaan bahan pangan sebagai energi alternatif dapat menimbulkan masalah baru yang terkait dengan pemenuhan kebutuhan pangan. Sebagai contoh, hanya untuk memproduksi 1 liter bioetanol dari ubi kayu dibutuhkan sekitar 6,5 kg ubi kayu. Hal ini tentu saja dapat mengancam ketahanan pangan nasional, dan bahkan mungkin dunia.

Di Indonesia, jagung merupakan komoditas pangan dengan tingkat permintaan yang terus meningkat. Badan Pusat Statistik (2008) memperkirakan pada tahun 2008 produksi jagung pipil kering di Indonesia sebanyak 14.854.050 ton. Jumlah ini dihasilkan oleh propinsi-propinsi penghasil jagung terbesar seperti Jawa Timur, Jawa Tengah, Lampung, Sumatera Selatan, Sumatera Utara, NTT, dan Gorontalo. Pada industri jagung pipil, akan dihasilkan limbah organik antara lain adalah limbah tongkol jagung. Sekarang ini, diketahui pula ternyata bioetanol dapat diproduksi dari bahan baku tanaman yang mengandung selulosa. Tongkol 
jagung mengandung selulosa sekitar 44,9\%. Jika umumnya jagung mengandung kurang lebih 30\% tongkol jagung, jumlah tongkol jagung di Indonesia pada tahun 2008 adalah sebanyak 6.366.021 ton. Padahal, setelah pemipilan biji, tongkol jagung dibuang dan menjadi limbah. Hal tersebut tentu saja akan menambah jumlah limbah tidak bermanfaat yang merugikan lingkungan jika tidak ditangani dengan benar.

Ekstraksi tongkol jagung menjadi xilan akan menghasilkan hasil samping berupa fraksi selulosa. Fraksi selulosa sebagai komponen terbesar dari tongkol jagung dan merupakan hasil samping ekstraksi hemiselulosa belum dimanfaatkan lebih lanjut. Padahal dengan pengolahan lanjut menggunakan hidrolisa baik secara enzimatis maupun asam dapat menghasilkan gulagula sederhana terutama glukosa dan difermentasi lanjut dengan mikroorganisme akan menghasilkan etanol. Pada umumnya kesulitan produksi alkohol dari bahan lignoselulosik seperti tongkol jagung adalah adanya perlakuan awal yang mahal seperti penghilangan lignin, pemisahan komponen dan hidrolisis sebelum fermentasi.

Penelitian ini bertujuan untuk mengetahui potensi dan karakteristik bioetanol dari limbah tongkol jagung manis yang difermentasi menggunakan mikroba Saccharomyses Cerevisiae.

\section{METODE PENELITIAN}

\section{Alat dan Bahan}

Peralatan yang dibutuhkan untuk pretreatment adalah pisau untuk mencacah tongkol jagung, alat penyerut jagung, timbangan analitik, gelas ukur, beaker glass, pipet tetes, labu erlenmeyer, tabung reaksi, rak tabung reaksi., pH-meter, labu ukur, dan pipet filler, botol fermentor selang dan spektrofotometer. Bahan baku yang digunakan dalam penelitian ini adalah tongkol jagung manis yang telah dicacah, Mikroba Saccharomyces Cerevisiae, Urea dan NPK, HCL, NaOH, Nelson A, Nelson B, Arsenol, Reagen Kalium Bikromat dan Karbonat, dan aquadest.

\section{Variabel Pengukuran}

Variabel dan pengukuran yang diamati dalam penelitian ini meliputi:

1. Kadar gula reduksi sebelum dan sesudah fermentasi (\% $\mathrm{m} / \mathrm{v})$

Kadar gula reduksi merupakan indikator kandungan glukosa pada substrat yang telah mengalami proses hidrolisis. Kadar gula reduksi yang terkandung dalam substrat diukur menggunakan spektrofotometer (Sudarmadji et al., 1989).

2. Kandungan etanol hasil fermentasi (\% v/v)

Kandungan etanol merupakan indikator kandungan etanol pada cairan yang telah mengalami proses fermentasi. Kandungan etanol yang terkandung dalam bioetanol dapat diukur menggunakan spektrofotometer berdasarkan nilai absorbansi (Kartika et al., 1992).

3. Rendemen bioetanol (\%)

Rendemen bioetanol dihitung dari hasil pengukuran bioetanol yang diperoleh dari hasil fermentasi dibagi dengan volume bahan dasar atau produk awal (Setyawan, 2012).

\section{Analisis Data}

Data pengaruh variasi variabel bebas perlakuan hidrolisis dan fermentasi terhadap variabelvariabel terikatnya yaitu kadar gula reduksi, kadar bioetanol, dan rendemen bioetanol, dianalisis dengan mnggunakan Analysis Of Variance (ANOVA) atau Uji F. Apabila perlakuan berpengaruh nyata terhadap parameter maka dilanjutkan dengan Uji Duncan Multiple Test (DMRT).

\section{HASIL DAN PEMBAHASAN}

\section{Analisis Substrat Bahan Baku Fermentasi}


Analisis sebelum fermentasi pada penelitian ini dilakukan sebagai uji pendahuluan. Kadar air merupakan salah satu bagian yang diuji sebelum melakukan proses fermentasi. Tabel 1 merupakan data kadar air tongkol jagung manis.

Tabel 1.

Hasil analisis kadar air tongkol jagung manis.

\begin{tabular}{cccc}
\hline Ulangan & $\begin{array}{c}\text { Berat Awal cawan+sampel } \\
(\mathrm{g})\end{array}$ & $\begin{array}{c}\text { Berat Akhir } \\
\text { cawan+sampel (g) }\end{array}$ & Kadar Air (\% bb) \\
\hline 1 & 48,86 & 44,63 & 82 \\
2 & 49,62 & 45,25 & 87 \\
3 & 45,30 & 41,07 & 83 \\
\hline Rata-rata & 47,92 & 43,65 & 84 \\
\hline
\end{tabular}

Tabel 1 menunjukan bahwa hasil uji kadar air pada ulangan 1 (U1), ulangan 2 (U2), dan ulangan 3 (U3) berturut-turut adalah 82\%, 87\%, dan 83\%. Berdasarkan analisis diatas maka kadar air rata-rata tongkol jagung manis didapatkan sebesar $84 \%$. Kadar air sangat penting untuk pertumbuhan mikroba. Kelembaban dan kadar air cenderung berpengaruh terhadap pertumbuhan mikroba.

\section{Hidrolisis dengan Metode SSF}

Proses hidrolisis dengan metode SSF (Simultaneous Saccharification and Fermentation) dilakukan secara serempak/simultan hidrolisis dan fermentasi. Proses SSF ini dilakukan dengan menggunakan satu reaktor untuk proses hidrolisis dan fermentasinya. Keuntungan dari proses ini adalah polisakarida yang terkonversi menjadi monosakarida tidak kembali menjadi polisakaridanya karena monosakaridanya langsung difermentasi menjadi etanol. Selain itu, penggunaan satu reaktor dalam prosesnya akan mengurangi biaya peralatan yang digunakan.

Pada saat setelah dilakukan pemanasan, tidak tercium bau manis pada sari tongkol jagung manis. Untuk proses fermentasinya juga tidak mengeluarkan $\mathrm{CO}_{2}$ atau dapat dilihat secara kasat mata larutan tersebut tidak mengeluarkan gelembung dan tercium asam (bau tidak sedap).

Tabel 2 .

Kadar Gula Awal Subsrat

\begin{tabular}{cc}
\hline Ulangan & Kadar Glukosa \% \\
\hline 1 & 2,88 \\
2 & 3,29 \\
3 & 0,48 \\
\hline Rata-rata & 2,21 \\
\hline
\end{tabular}

Tabel 2 menunjukan bahwa hasil uji gula substrat awal sebelum fermentasi pada ulangan 1 (U1), ulangan 2 (U2), dan ulangan 3 (U3) berturut-turut adalah sebesar 2,88\%; 3,29\%; 0,48\%; dan rata-rata kadar gula awal yang diperoleh sebesar 2,21\%. Maka rata-rata kadar gula awal dari tongkol jagung manis dapat dikatakan rendah, sesuai dengan pernyataan dari Yang (1953) menyatakan bahwa pada awal fermentasi kadar gula yang baik adalah 12-16\%, gula dalam substrat akan mempercepat pertumbuhan sel khamir. Bila gula sudah habis, dapat ditambahkan lagi untuk memperoleh kandungan alkohol yang cukup tinggi. Makin tinggi kadar glukosa dalam buah, kemungkinan alkohol yang dihasilkan akan semakin tinggi, apabila glukosa awal terlalu tinggi, akan mempengaruhi proses fermentasi karena akan terjadi yang disebut dengan glukosa efek. Jika glukosa tinggi tekanan osmosis di dalam larutanpun akan tinggi daripada di dalam sel. Sehingga cairan yang ada di dalam sel khamir akan cenderung keluar dari sel, hal ini mengakibatkan sel mengkerut dan mati. Oleh sebab itu perlu dijaga agar kadar glukosa di dalam larutan tidak berlebih. 


\section{Analisis Setelah Fermentasi}

Pengaruh perlakuan terhadap kadar gula reduksi.

Berdasarkan hasil fermentasi bioetanol dari tongkol jagung manis menggunakan Saccharomyces Cereviceae kadar gula reduksi bioetanol dengan berbagai perlakuan ditunjukan pada Tabel 3.

Tabel 3.

Kadar gula reduksi setelah fermentasi

\begin{tabular}{ccccc}
\hline \multirow{2}{*}{ Perlakuan } & \multicolumn{3}{c}{ Kadar gula reduksi $(\% \mathrm{~m} / \mathrm{v})$} & \multirow{2}{*}{ Rata-rata $(\% \mathrm{~m} / \mathrm{v})$} \\
\cline { 2 - 4 } & $\mathrm{I}$ & $\mathrm{II}$ & $\mathrm{III}$ & 0,325 \\
S1T1 & 0,108 & 0,323 & 0,544 & 0,500 \\
S2T1 & 0,394 & 0,512 & 0,595 & 0,388 \\
S3T1 & 0,357 & 0,459 & 0,349 & 0,373 \\
S4T1 & 0,414 & 0,270 & 0,436 & 0,691 \\
S1T2 & 0,986 & 0,503 & 0,584 & 0,406 \\
S2T2 & 0,437 & 0,306 & 0,476 & 0,410 \\
S3T2 & 0,424 & 0,382 & 0,424 & 0,574 \\
S4T2 & 0,419 & 0,515 & 0,788 & 0,942 \\
S1T3 & 0,865 & 0,819 & 1,142 & 0,755 \\
S2T3 & 0,818 & 0,698 & 0,751 & 0,813 \\
S3T3 & 0,972 & 0,941 & 0,528 & 0,560 \\
S4T3 & 0,501 & 0,578 & 0,601 & 6,737 \\
Total & 6,695 & 6,306 & 7,218 & 0,561 \\
\hline Rata-rata & 0,558 & 0,525 & 0,601 & \\
\hline
\end{tabular}

Tabel 3 menunjukkan bahwa kadar gula reduksi setelah fermentasi pada berbagai kombinasi perlakuan yang dihasilkan meningkat pada setiap perlakuan hari. Dengan rata-rata kadar gula reduksi tertinggi adalah pada konsentrasi mikroba $0 \%$ dan lama fermentasi 6 hari. Hal tersebut karena lama fermentasi lebih berpengaruh daripada konsentrasi mikroba. Menurut Kunaepah (2008) dalam Azizah (2012), ada banyak faktor yang mempengaruhi fermentasi antara lain substrat, suhu, waktu fermentasi, $\mathrm{pH}$, oksigen, dan mikroba yang digunakan.

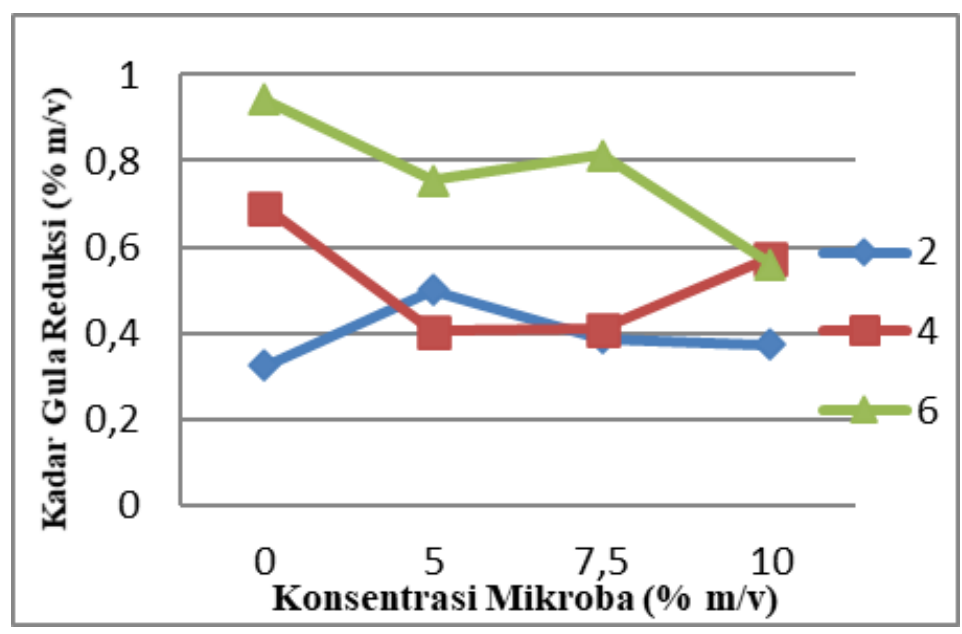

Gambar 1. Kadar Gula Setelah Fermentasi 
Gambar 1 menunjukan bahwa fermentasi 2 hari (T1) tersisa gula reduksi pada konsentrasi Saccharomyces Cereviceae yaitu 0\% (S1), 5\% (S2), dan 7,5\% (S3) dan 10\% (S4) berturut-turut adalah $0,325 \% \mathrm{~m} / \mathrm{v}, 0,500 \% \mathrm{~m} / \mathrm{v}, 0,388 \% \mathrm{~m} / \mathrm{v}$ dan $0,373 \% \mathrm{~m} / \mathrm{v}$. Pada fermentasi 4 hari (T2) tersisa gula reduksi cukup tinggi pada konsentrasi Saccharomyces Cereviceae yaitu 0\% (S1), $5 \%$ (S2), 7,5\% (S3) dan 10\% (S4) berturut-turut adalah 0,691\% m/v, 0,406\% m/v, 0,410\% m/v dan $0,574 \% \mathrm{~m} / \mathrm{v}$. Pada fermentasi 6 hari (T3) terjadi penaikan sisa gula reduksi dengan konsentrasi Saccharomyces Cereviceae yaitu 0\% (S1), 5\% (S2), 7,5\% (S3) dan 10\% (S3) berturut-turut adalah 0,942\% m/v, 0,755\% m/v, 0,813\% m/v dan 0,560\% m/v. Menurut Arif et al. (2016), gula sederhana yang tersedia tidak semuanya dapat dimanfaatkan oleh Saccharomyces Cereviceae. Karena mikroba tersebut hanya dapat menggunakan glukosa, fruktosa, maltosa dan galaktosa, sedangkan gula lain yang tidak dapat dimanfaatkan oleh khamir tertinggal dalam larutan.

Berdasarkan Analysis of Variance (ANOVA), pengaruh konsentrasi Saccharomyces Cereviceae. dan lama fermentasi serta hubungan keduanya terhadap kadar gula reduksi setelah fermentasi disajikan dalam Tabel 4.

Tabel 4.

ANOVA (pengaruh perlakuan terhadap kadar gula reduksi)

\begin{tabular}{lccccl}
\hline Sourch of Variation & $S S$ & $d f$ & $M S$ & F hitung & F 5\% \\
\hline Konentrasi Mikroba (S) & 0,111 & 3 & 0,037 & $1,598^{*}$ & $3,008^{*}$ \\
Lama fermentasi (T) & 0,856 & 2 & 0,428 & $18,360^{* *}$ & $3,402^{* *}$ \\
Interaksi & 0,336 & 6 & 0,056 & $2,402^{*}$ & $2,508^{*}$ \\
S dan T & 0,560 & 24 & 0,023 & & \\
Error (Galat) & 1,865 & 35 & & & \\
Total & & & & & \\
\hline
\end{tabular}

Keterangan :

* = tidak berpengaruh nyata

** = berpengaruh nyata

Tabel 4 menunjukkan bahwa lama fermentasi berpengaruh nyata terhadap kadar gula reduksi, sedangkan konsentrasi Saccharomyces Cereviceae, dan interaksinya dengan lama fermentasi tidak berpengaruh nyata terhadap kadar gula reduksi. Analisis selanjutnya dengan menggunakan Uji Duncan Multiple Range Test (DMRT) memberikan hasil seperti disajikan pada Tabel 5.

Tabel 5.

Hasil uji (DMRT) pada perlakuan lama fermentasi

\begin{tabular}{cc}
\hline Lama fermentasi (hari) & Rata-rata kadar gula reduksi (\%) \\
\hline 2 & $3,435(\mathrm{a})$ \\
4 & $4,991(\mathrm{a})$ \\
6 & $8,133(\mathrm{~b})$ \\
\hline
\end{tabular}

Keterangan:

Notasi huruf yang sama menunjukan perlakuan tidak berpengaruh nyata pada taraf uji Duncan $5 \%$

Tabel 5 menunjukkan bahwa 2 hari (T1) adalah fermentasi terbaik, karena kadar gula reduksi yang tersisa pada fermentasi 2 hari (T1) paling rendah, namun pada fermentasi 4 hari (T2) kadar gula reduksi yang tersisa juga tidak berbeda signifikan dengan kadar gula reduksi yang tersisa pada fermentasi 2 hari (T1) atau dapat dikatakan sama 
Hasil Analysis Of Variance (ANOVA) dan uji lanjut (DMRT) diperoleh perlakuan kadar gula terbaik adalah pada konsentrasi mikroba 0\% dan lama fermentasi 2 hari (S1T1) karena rata-rata kadar gula reduksi yang tersisa paling rendah. Karena semakin sedikit gula reduksi yang tersisa, maka semakin banyak pula gula reduksi yang terkonversi menjadi etanol. Kadar gula reduksi mengalami penurunan selama proses fermentasi , hal ini dikarenakan gula yang terdapat pada medium fermentasi terus menerus dimanfaatkan oleh sel Saccharomyces Cerevisiae untuk pertumbuhan sel dan pembentukan etanol. Semakin banyak gula reduksi yang dimanfaatkan oleh sel Saccharomyces Cerevisiae maka konsentrasi etanol yang dihasilkan semakin tinggi dan sebaliknya semakin sedikit gula reduksi yang dimanfaatkan maka konsentrasi etanol yang dihasilkan semakin rendah. Hal ini sesuai dengan pernyataan Wignyanto et al. (2001) yang menyatakan bahwa semakin banyak gula reduksi yang dapat dimanfaatkan oleh sel Saccharomyces Ccerevisiae maka konsentrasi etanol yang dihasilkan oleh sel Saccharomyces Cerevisiae semakin tinggi. Gula yang terdapat pada medium fermentasi dirombak menjadi etanol dengan melibatkan aktivitas enzim dari sel Saccharomyces Cerevisiae.

\section{Pengaruh perlakuan terhadap kadar bioetanol}

Berdasarkan pengukuran kadar bioetanol dari setiap perlakuan diperoleh kadar bioetanol yang disajikan pada Tabel 6 .

Tabel 6.

Kadar bioetanol hasil pengukuran.

\begin{tabular}{ccccc}
\hline \multirow{2}{*}{ Perlakuan } & \multicolumn{3}{c}{ Kadar Bioetanol (\% v/v) } & \multirow{2}{*}{ Rata-rata (\% v/v) } \\
\cline { 2 - 4 } & I & II & III & 0,489 \\
S1T1 & 0,506 & 0,498 & 0,463 & 0,510 \\
S2T1 & 0,539 & 0,524 & 0,467 & 0,431 \\
S3T1 & 0,362 & 0,456 & 0,477 & 0,469 \\
S4T1 & 0,481 & 0,419 & 0,507 & 0,549 \\
S1T2 & 0,580 & 0,432 & 0,637 & 0,529 \\
S2T2 & 0,503 & 0,554 & 0,532 & 0,557 \\
S3T2 & 0,503 & 0,642 & 0,526 & 0,526 \\
S4T2 & 0,492 & 0,507 & 0,579 & 0,518 \\
S1T3 & 0,531 & 0,501 & 0,522 & 0,548 \\
S2T3 & 0,552 & 0,601 & 0,493 & 0,533 \\
S3T3 & 0,492 & 0,537 & 0,572 & 0,538 \\
S4T3 & 0,555 & 0,523 & 0,537 & 6,200 \\
Total & 6,096 & 6,194 & 6,312 & 0,516 \\
\hline Rata-rata & 0,508 & 0,516 & 0,526 & \\
\hline
\end{tabular}

Tabel 6 menunjukkan bahwa bioetanol yang dihasilkan masih sangat rendah dengan rata-rata kadar bioetanol tertinggi $0,557 \%(\mathrm{v} / \mathrm{v})$. Hasil etanol yang didapatkan sangat rendah. Dapat diartikan percobaan tersebut tidak menghasilkan etanol yang signifikan. Setelah proses pemanasan dilakukan "tidak tercium bau manis" yang menandakan proses hidrolisis berjalan dengan tidak baik karena adanya konversi dari selulosa menjadi glukosa. Larutan hasil fermentasi tersebut tidak menghasilkan gelembung yang menandakan adanya $\mathrm{CO}_{2}$ yang dihasilkan dari reaksi fermentasi yang berhasil.

Berdasarkan hasil pengukuran kadar etanol dari tiap perlakuan dan konsentrasi Saccharomyses Cerevisiae dan lama fermentasi, menghasilkan etanol yang sangat rendah. Hal ini karena penggunaan asam untuk hidrolisis memiliki banyak kelemahan diantaranya: menghasilkan produk samping seperti senyawa furan, fenolik dan asam asetat yang dapat menghambat pertumbuhan mikroba, bersifat korosif terhadap peralatan yang digunakan, 
menghasilkan glukosa rendah, membutuhkan suhu yang tinggi dan lain-lain (Taherzadeh dan Keikhosrok, 2007).

Proses hidrolisis SSF dengan asam encer memiliki keterbatasan pada efisiensi recovery gula. Hal ini dikarenakan pada proses degradasi gula terjadi pembentukan produk yang tidak diinginkan seperti furfural yang merupakan bahan kimia yang digunakan dalam industri plastik. Furfural ini dapat mematikan mikroorganisme yang melakukan proses fermentasi (Badger, 2002).

Berbeda jika melakukan hidrolisis SSF dengan menggunakan enzim, menurut (Taherzadeh dan Karimi, 2007; Olofsson et al., 2008), penggunaan metode SSF dengan memakai enzim dapat mencegah terhambatnya kerja enzim oleh produk glukosa dan selobiosa yang selama ini menjadi kelemahan dari metode pembuatan etanol.

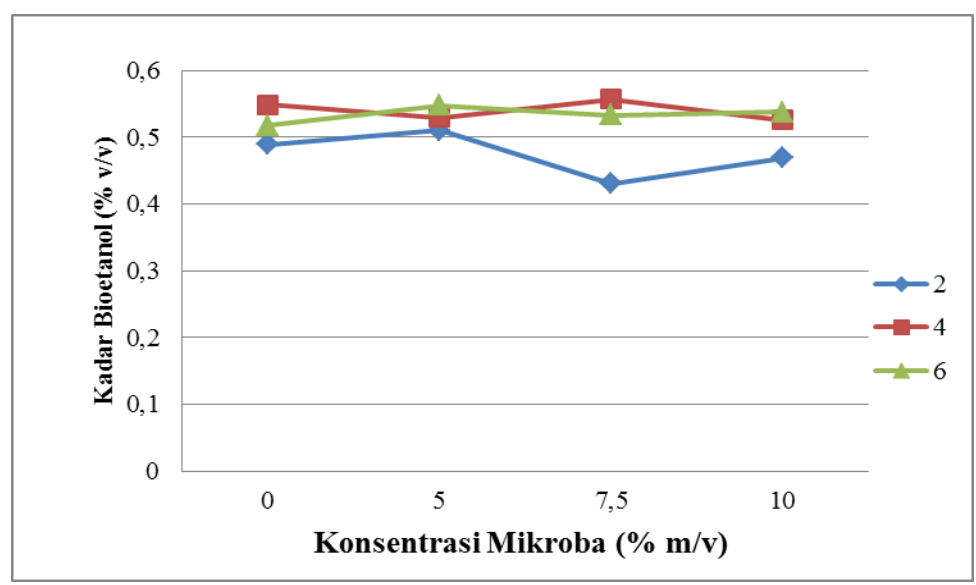

Gambar 2. Hasil Kadar Bioetanol

Gambar 2 menunjukan hubungan kadar bioetanol dan lama fermentasi dengan masingmasing kombinasi perlakuan, diantaranya fermentasi 2 hari (T1) dan konsentrasi Saccharomyces Cereviceae yaitu 0\% (S1), 5\% (S2), 7,5\% (S3) dan 10\% (S4) berturut-turut adalah 0,489\% v/v, 0,510\% v/v, 0,431\% v/v dan 0,469\% v/v. Fermentasi 4 hari (T2) dan konsentrasi Saccharomyces Cereviceae yaitu 0\% (S1), 5\% (S2), 7,5\% (S3) dan 10\% (S4) berturut-turut adalah 0,549\% v/v, 0,529\% v/v, 0,557\% v/v dan 0,526\% v/v. Fermentasi 6 hari (T3) dan konsentrasi Saccharomyces Cereviceae yaitu 0\% (S1), 5\% (S2), 7,5\% (S3) dan 10\% (S4) berturut-turut adalah 0,518\% v/v, 0,548\% v/v, 0,533\% v/v dan 0,538\% v/v. Pada fermentasi 2 hari (T1) terjadi kenaikan kadar bioetanol pada konsentrasi Saccharomyces Cereviceae yaitu 5\% (S2), dan terjadi penurunan kadar bioetanol pada konsentrasi Saccharomyces Cereviceae yaitu 7,5\% (S3) dan terjadi penaikan kadar bioetanol pada konsentrasi Saccharomyces Cereviceae yaitu 10\% (S4). Pada fermentasi 4 hari (T2) terjadi penaikan dan penurunan kadar bioetanol yang tidak signifikan pada setiap konsentrasi Saccharomyces Cereviceae 0\% (S1), 5\% (S2), 7,5\% (S3) dan 10\% (S4). Pada fermentasi 6 hari (T3) diperoleh kadar bioetanol yang hampir sebanding pada setiap konsentrasi Saccharomyces Cereviceae yaitu 0\% (S1), 5\% (S2), 7,5\% (S3) dan 10\% (S4). Menurut pernyataan Budiyanto (2003), Tinggi rendahnya kadar etanol yang diperoleh bisa dipengaruhi oleh pertumbuhan sel mikroba yang digunakan selama proses fermentasi. Cepat lambatnya pertumbuhan dipengaruhi oleh beberapa faktor diantaranya komposisi media, pemilihan yeast, nutrisi, kandungan gula, derajat keasaman $(\mathrm{pH})$, oksigen, dan suhu. Fermentasi dapat berjalan secara optimum ketika pertumbuhan enzim maksimum dan ketersediaan substrat cukup.

Berdasarkan Analysis of Variance (ANOVA), pengaruh konsentrasi Saccharomyces Cereviceae dan lama fermentasi serta hubungan keduanya terhadap kadar bioetanol disajikan dalam Tabel 7.Tabel 7 menunjukkan bahwa lama, konsentrasi mikroba Saccharomyces Cereviceae. dan interaksinya dengan waktu fermentasi semuanya tidak berpengaruh nyata terhadap kadar bioetanol. 
Tabel 7.

ANOVA (Pengaruh perlakuan terhadap kadar bioetanol)

\begin{tabular}{lrllll}
\hline Source of Variation & $S S$ & $d f$ & $M S$ & $F$ hitung & $F 5 \%$ \\
\hline Konentrasi Mikroba (S) & 0,021 & 3 & 0,007 & $2,465^{*}$ & $3,008^{*}$ \\
Lama fermentasi (T) & 0,002 & 2 & 0,001 & $0,330^{*}$ & $3,402^{*}$ \\
Interaksi & 0,015 & 6 & 0,002 & $0,860^{*}$ & $2,508^{*}$ \\
S dan T & 0,070 & 24 & 0,002 & & \\
Error (Galat) & 0,109 & 35 & & & \\
Total & & & & & \\
\hline
\end{tabular}

Keterangan :

* = tidak berpengaruh nyata

** = berpengaruh nyata

\section{KESIMPULAN}

Perlakuan fermentasi pada variasi konsentrasi mikroba Saccharomyses Cerevisiae menggunakan bahan cacahan tongkol jagung manis menghasilkan kadar etanol yang sangat rendah dengan rata-rata kadar bioetanol tertinggi sebesar 0,557\% (v/v) hasil kombinasi perlakuan konsentrasi mikroba 7,5\% dengan waktu fermentasi 4 hari (S3T2). Serta konsentrasi mikroba tidak berpengaruh nyata terhadap kadar gula reduksi dan kadar bioetanol, sedangkan lama fermentasi berpengaruh nyata terhadap kadar gula reduksi.

\section{DAFTAR PUSTAKA}

Arif, A. B., Diyono, W., Budiyanto, A., \& Richana, N. (2016). Analisis Rancangan Faktorial Tiga Faktor untuk Optimalisasi Produksi Bioetanol dari Molases Tebu. Jurnal Informatika Pertanian, 25 (1).

Badger, P. C. (2002). Etanol From Cellulose: A general review. in: J. Janick and A. Whipkey (ed.). Trends in New Crops and New Uses (pp. 17-21). Alexandria. VA: ASHS Press.

Budiyanto, M. A. K. (2003). Mikrobiologi Terapan. Malang: UMMPers.

Kartika, B., Guritno, A. D., Purwadi, D., \& Ismoyowati, D. (1992). Petunjuk Evaluasi Produk Industri Hasil Pertanian. Yogyakarta: PAU Pangan dan Gizi UGM.

Kunaepah, U. (2008). Pengaruh Lama Fermentasi dan Konsentrasi Glukosa terhadap Aktivitas Antibakteri, Polifenol Total dan Mutu Kimia Kefir Susu Kacang Merah. Tesis. Semarang: Universitas Diponegoro.

Setyawan, A. (2012). Kajian Eksperimental Pengaruh Etanol pada Premium Terhadap Karakteristik Pembakaran Kondisi Atmosferik dan Bertekanan di Motor Otto Silinder Sistem Injeksi. Disertasi. Jakarta: Teknik Mesin Fakultas Teknik Universitas Indonesia.

Sudarmadji. S., Haryono, B. \& Suhardi. (1989). Mikrobiologi Pangan. Yogyakarta: PAU Pangan dan Gizi Universitas Gadjah Mada.

Taherzadeh, M. J., Karimi, K. (2007). Enzyme-based Hydrolysis Processes for Ethanol from Lignocellulosics Materials: A Review. Bioresources, 2(4): 707-738.

Wignyanto, Suharjono \& Novita. (2001). Pengaruh Konsentrasi Gula Reduksi Sari Hati Nanas dan Inokulum Saccharomyces Cerevisiae pada Fermentasi Etanol. Jurnal Teknologi Pertanian 2 (1): 68-77.

Yang, H. Y., (1953). Fruit Wines Requiaities for Succesful Fermentation, Agricultural and Food Chemistry, Vol. 1. 